\section{Resistance of Mice and Rats to Challenge by Babesia rodhaini after Inoculation with Irradiated Red Cells infected with B. rodhaini}

FIELD vaccination of cattle against babesia parasites is performed by infecting with a strain of low virulence ${ }^{1}$. This unfortunately ensures continued transmission of the disease. Some resistance has been induced experimentally in rats ${ }^{2,3}$ and cattle ${ }^{4}$ by injection of killed piroplasms using large amounts of parasite antigen, often combined with an adjuvant. I present here a preliminary account of successful protective immunization of mice and rats against the piroplasm Babesia rodhaini using irradiated piroplasms.

Parkes mice and Sprague-Dawley rats were used. The rat-adapted strain of $B$. rodhaini, which is easily transferable to mice, was not contaminated with Eperythrozoon coccoides $^{5}$. A stabilate ${ }^{6}$ of infected blood was frozen to $-70^{\circ} \mathrm{C}$ at the start of each experiment to ensure that a strict homologous challenge of vaccinated animals was subsequently made.

Blood was taken from uninfected or infected donors by cardiac puncture, using heparin $(17 \mathrm{IU} / \mathrm{ml}$.) as the anticoagulant, and held on ice until irradiated at $22^{\circ} \pm 2^{\circ} \mathrm{C}$ with approximately $1,000 \mathrm{rad} / \mathrm{min}$ from a $\gamma$-beam ${ }^{60} \mathrm{Co}$ 650 source. Immunizing and challenge inocula were given intraperitoneally. Parasitaemias were determined by examination of Giemsa-stained films of peripheral blood and recorded as the number of parasitized red cells in $10^{5}$ red cells.

Groups of five or six mice were injected with $2 \times 10^{9}$ infected mouse red cells which had been irradiated with doses of 5, 1.0, 20, 40 or $80 \mathrm{krad}$. During the succeeding 20 days recipient mice were examined for piroplasms. As Table 1 shows, only doses of 40 or $80 \mathrm{krad}$ rendered the piroplasms non-infective. On day 20 after immunization the mice in the latter two groups, together with control mice which had been injected with irradiated normal red cells, were challenged with $1 \times 10^{5}$ parasitized red cells. Comparison of the geometrical mean parasitaemias for each group following challenge showed that the mice inoculated with irradiated piroplasms developed patent parasitaemias 3-4 days after the controls and more of them survived.

Table 1. INFECTIVTY OF IRRADIATED MOUSE RED CELLS PARASITIZED BY

\begin{tabular}{|c|c|c|c|c|}
\hline \multirow{4}{*}{$\begin{array}{l}\text { Rudiation } \\
\text { received by } \\
\text { infected red cells } \\
\text { (Krad) }\end{array}$} & \multicolumn{3}{|c|}{ Babesia rodhaini } & \\
\hline & \multirow{3}{*}{$\begin{array}{l}\text { No. of mice which } \\
\text { developed an infection } \\
\text { after receiving } \\
\text { irradiated blood }\end{array}$} & \multicolumn{3}{|c|}{$\begin{array}{l}\text { No. of infected mice } \\
\text { which died }\end{array}$} \\
\hline & & \multirow{2}{*}{ No. } & \multicolumn{2}{|c|}{ Day of death } \\
\hline & & & Mean & Range \\
\hline $\begin{array}{r}5 \\
10\end{array}$ & $\begin{array}{l}5 / 5 \\
5 / 5\end{array}$ & $5 / 5$ & $\begin{array}{l}6 \\
8.4\end{array}$ & $\begin{array}{r}5-7 \\
7-10\end{array}$ \\
\hline $\begin{array}{l}20 \\
40\end{array}$ & $\begin{array}{l}6 / 6 \\
0 / 5\end{array}$ & & $16 \cdot 6$ & $16-18$ \\
\hline 80 & $0 / 6$ & & & \\
\hline
\end{tabular}

Other experiments with mice were carried out with essentially similar results.

Protective immunization of rats by inoculations of irradiated $B$, rodhaini infected red cells was much more effective than that of mice. $60-80 \mathrm{~g}$ rats were inoculated with $1-2 \times 10^{9}$ infected rat red cells which had been inactivated with $60 \mathrm{krad}$. The results of a typical experiment are given in Fig. 1. Not only was the patent parasitaemia following challenge delayed by about 8 days in the immunized rats but it was also considerably depressed. A fuller account of these experiments is in preparation.

Although the immunizing inocula contained many parasitized cells the strength of the immunity observed in the immunized rats suggests that smaller immunizing inocula can be expected to be effective at least in this host. This type of approach in the control of economically important piroplasms could be worth while even when taking into account the problems associated with intraspecific $^{7}$ variation.

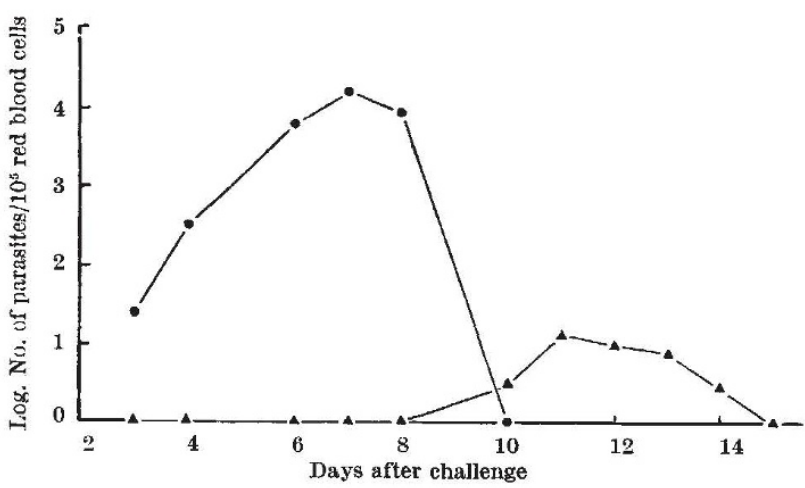

Fig. 1. The immunized rats received $1.5 \times 10^{9} \mathrm{rat}$ red cells infected with $B$. rodhaini, and irradiated with $60 \mathrm{krad}$. Controls (Q) received uninfected blood irradiated with $60 \mathrm{krad}$. Challenge (A) was with $1 \times 10^{\circ}$ parasitized rat red cells 19 days after the immunizing inocula. The para-
sitaemias in the flgure are the geometrical means of five rats.

I thank Mrs J. Page for technical assistance and my colleagues for helpful criticism. Mr D. Lee irradiated the blood.

Division of Parasitology,

R. S. Phillips

National Institute for Medical Research,

Mill Hill, London NW7.

Received March 26; revised May 26, 1970.

'Callow, L. L., and Tammemagi, L., Austral. Vet. J., 43, 249 (1967).

${ }^{2}$ Phillips, R. S., Parasitology, $11 \mathrm{P}$ (1967).

3 Phillips, R. S., thesis, Univ. Cambridge (1968).

4 Mahoney, D. F., Exp. Parasitol., 20, 125 (1967)

5 Voller, A., and Bidwell, D. E., Ann. Trop. Med. Parasitol., 62, 342 (1968).

${ }^{6}$ Lumsden, W. H. R., and Hardy, G. T. C., Nature, 250, 1032 (1965).

'Phillips, R. S., Parasitology, 59, 349 (1969).

\section{Renal Prostaglandins: Possible Regulators of the Renal Actions of Pressor Hormones}

We describe here the release from the kidney by angiotensin II and noradrenaline of substances which have the properties of prostaglandins. This observation may help to account for the antihypertensive function of the kidney first suggested by Fasciolo $^{1}$, who demonstrated that removal of the kidney contralateral to an ischaemic kidney produced sustained hypertension in dogs. We have adapted the bioassay method of Vane ${ }^{2}$, the super' fused blood-bathed organ technique, for the detection of prostaglandins in renal venous blood in response to infusions of angiotensin II or noradrenaline into the renal artery.

Male mongrel $\operatorname{dog}_{5}(22-35 \mathrm{~kg})$ were anaesthetized with morphine sulphate (2 mg/kg, subcutaneously) and chloralose (100 mg/kg, intravenously). Anaesthesia was maintained with chloralose $(40 \mathrm{mg} / \mathrm{kg})$. The trachea was: cannulated and the lungs were ventilated mechanically. The abdominal cavity was opened by a transverse incision and the right renal artery and right ureter were isolated. Two Hewlett-Packard direct writers recorded: (1) mean aortic blood pressure measured by a Statham transducer ('P23Db'); (2) renal blood flow measured by an electromagnetic flowmeter ('Statham M-4001'); (3) changes in length of assay organs as detected by Harvard isotonic transducers; and (4) urine drops counted by a Grass photoelectric transducer ('PT'TI'). Rat stomach strip, rat colon and chick rectum, which were reported by Ferreira and Vane $^{3}$ to possess the required specificity and sensitivity for the detection of prostaglandins were used as assay organs. The assay tissues were loaded with 1 to 3 